\title{
HUBUNGAN CITRA TUBUH TERHADAP KEPERCAYAAN DIRI PADA REMAJA PUTRI DI MA SABILUL HASANAH BANYUASIN TAHUN 2019
}

\author{
Tafdhila ${ }^{1}$, Umi Chania ${ }^{2}$ \\ Dosen STIK Siti Khadijah Palembang \\ Mahasiswa STIK Siti Khadijah Palembang \\ Email: Tafdhila23@gmail.com
}

\begin{abstract}
ABSTRAK
Citra tubuh adalah penilaian dari pengalaman perasaan seseorang mengenai karakteristik dirinya. Kepercayaan diri merupakan suatu keyakinan seseorang terhadap segala kelebihan aspek yang dimilikinya dan keyakinan tersebut membuatnya merasa mampu untuk bisa mencapai berbagai tujuan di dalam hidupnya. Individu yang percaya diri akan merasa yakin terhadap dirinya sendiri. Penelitian ini bertujuan diketahuinya hubungan citra tubuh terhadap kepercayaan diri pada remaja putri. Desain penelitian menggunakan kuantitatif dengan metode survey analitik melalui pendekatan cross sectional. Populasi dalam penelitian ini adalah semua remaja putri kelas 1 dan 2 MA Sabilul Hasanah Banyuasin tahun 2019 sebanyak 229. Sampel penelitian berjumlah 68 orang, teknik pengambilan sampel menggunakan accidental sampling. Instrumen penelitian menggunakan kuesioner. Analisis bivariat menggunakan uji Chi-Square dengan tingkat kemaknaan $(\alpha=0.05)$.. Hasil penelitian ini didapatkan bahwa terdapat hubungan antara citra tubuh dengan kepercayaan diri pada remaja putri di MA Salibul Hasanah ( $p$ value 0,007). Simpulan penelitian ini terdapat hubungan antara citra tubuh dengan kepercayaan diri pada remaja putri di MA Salibul Hasanah tahun 2019. Disarankan untuk remaja putri agar lebih memperhatikan body image sehingga lebih meningkatkan rasa percaya diri, dan untuk peran orang tua agar memuji dan menyayangi anak sehingga anak merasa tidak ada kekurangan dalam dirinya.
\end{abstract}

\section{Kata Kunci : Citra Tubuh, Kepercayaan Diri, Remaja, Putri}

\begin{abstract}
Body image is an assessment of one's feeling experience regarding one's characteristics. Selfconfidence is a person's belief in all the excess aspects that he has and that belief makes him feel able to achieve various goals in his life. A confident individual will feel confident about himself. This study was aimed to determine the relationship of body image of confidence in adolescent girls.. The research design uses quantitative analytic survey methods through a cross sectional approach. The population in this study were all adolescent girls grade 1 and 2 MA Sabilul Hasanah Banyuasin in 2019 as many as 229. The research sample was 68 people, the sampling technique used accidental sampling. The research instrument used a questionnaire. Bivariate analysis using paired Chi-Square with significance level $(\alpha=0.05)$. The results of this study found that there is a relationship between body image with selfconfidence in young women at MA Salibul Hasanah ( $p$ value 0.007). The conclusion of this research is that there is a relationship between body image and self-confidence in young women in MA Salibul Hasanah in 2019. It is recommended for young women to pay more attention to body image so as to increase self-confidence, and for the role of parents to praise and love children so that children felt there was no shortage in him.
\end{abstract}

Keywords $\quad$ : Body Image, Self Confidence, Teenagers, Girls 


\section{PENDAHULUAN}

Remaja, yang dalam bahasa aslinya disebut adolescence, berasal dari bahasa latin adolescere yang artinya "tumbuh untuk mencapai kematangan”. Bangsa primitive dan orang-orang purbakala memandang masa puber dan masa remaja tidak berbeda dengan periode lain dalam rentang kehidupan. Anak dianggap sudah dewasa apabila sudah mampu mengadakan reproduksi. Asrori, dkk (2018).

Menurut Santrock (2007) dalam Ifdil (2017) masa remaja dimulai sekitar usia 10 hingga 13 tahun dan berakhir sekitar usia 18 hingga 22 tahun. Individu yang tergolong remaja akhir cenderung berada dalam keadaan labil dan emosional karena mengalami banyak perubahan-perubahan yang berlangsung cepat.

Menurut Papalia (2011) dalam Ifdil,dkk (2015) perubahan fisik menimbulkan dampak psikologis yang tidak diinginkan. Mayoritas anak muda lebih banyak memperhatikan penampilan mereka ketimbang aspek lain dalam diri mereka, dan banyak di antara mereka yang tidak suka melihat apa yang mereka lihat di cermin. Anak perempuan memiliki perasaan tidak suka yang lebih tinggi dibandingkan anak laki-laki, mencerminkan penekanan kultural yang lebih besar terhadap atribut fisik wanita.

Pada usia rentangan usia 16-20 tahun, seorang wanita mulai menemukan nilainilai hidup baru, sehingga semakin jelaslah pemahaman tentang keadaan diri sendiri Munculnya penilaian dikalangan remaja putri tentang standar tubuh saat ini yang mementingkan penampilan fisik dengan bentuk tubuh yang proposional, telah membuat remaja putri saat ini menjadi kurang percaya diri, remaja putri selalu menilai dirinya melalui kaca mata oranglain yaitu teman-teman sepergaulannya. Zadrian, dkk (2013) dalam Ifdil, dkk (2015).

Ratnawati (2012) dalam Ifdi,dkk (2015).. Berawal dari penampilan fisik, remaja mulai memberikan gambaran dan persepsi tentang bentuk fisik yang dimiliki, kemudian beranjak pada penampilan fisik yang dimiliki orang lain hingga standar tubuh yang harus dimiliki setiap perempuan. Gambaran dan persepsi tentang penampilan fisik inilah yang disebut citra tubuh.

Menurut Arthur (2010) dalam Ifdil, dkk (2015) body image adalah imajinasi subyektif yang dimiliki seseorang tentang tubuhnya, khususnya yang terkait dengan penilaian orang lain, dan seberapa baik tubuhnya harus disesuaikan dengan persepsi-persepsi ini.

Menurut Cash (1994) dalam Supriyadi, dkk (2015) citra tubuh adalah penilaian dari pengalaman perasaan seseorang mengenai karakteristik dirinya. Sedangkan menurut Emily (2010) dalam Supriyadi, dkk (2015) citra tubuh adalah imajinasi subjektif seseorang terhadap fisiknya yang berkaitan dengan penilaian orang lain.

Menurut Surya (2009) Supriyadi,dkk, (2015) menyatakan bahwa seorang akan percaya diri ketika orang tersebut menyadari bentuk tubuhnya yang sangat ideal dan orang tersebut merasa puas melihat bentuk tubuhnya, maka body image yang terbentuk pun menjadi positif. Sebaliknya, jika seseorang memandang tubuhnya tidak ideal seperti wajahnya kurang menarik, badannya terlalu gemuk atau terlalu kurus dan sebagainya, maka orang tersebut menjadi sibuk memikirkan kondisi fisiknya, sehingga body image yang terbentuk menjadi negatif dan dapat dikatakan orang tersebut tidak memiliki kepercayaan diri.

Menurut Hakim (2005) dalam Dewi (2013) kepercayaan diri merupakan suatu keyakinan seseorang terhadap segala kelebihan aspek yang dimilikinya dan keyakinan tersebut membuatnya merasa mampu untuk bisa mencapai berbagai tujuan di dalam hidupnya. Individu yang percaya diri akan merasa yakin terhadap dirinya sendiri.

Menurut Fatimah (2006) Denich,dkk (2017) menjelaskan bahwa kepercayaan diri adalah sikap positif seorang individu yang memampukan dirinya untuk 
mengembangkan penilaian positif, baik terhadap diri sendiri maupun terhadap lingkungan/situasi yang dihadapinya. Idealnya kepercayaan diri yang dimiliki individu haruslah berada pada kategori sangat tinggi. Hal ini dimaksud seorang individu untuk mengembangkan aspekaspek yang ada dalam dirinya membutuhkan kepercayaan diri tinggi. Namun, kenyataan yang ada di lapangan masih banyak individu, terutama remaja yang memiliki kepercayaan diri rendah.

Dari studi pendahuluan yang dilakukan peneliti di MA Sabilul Hasanah didapatkan 15 orang siswi yang telah di wawancarai. Dari 15 orang siswi tersebut, terdapat 9 orang siswi yang mempunyai kepercayaan diri rendah terhadap citra tubuh nya 4 diantaranya memiliki badan gemuk dan 5 siswi lainnya mempunyai jerawat di muka.

Pentingnya peningkatan kepercayaan diri terhadap citra tubuh diperkuat dari hasil penelitian. Farida (2014) menunjukan 25\% kepercayaan diri remaja pada kategori sedang, $75 \%$ kepercayaan diri pada remaja pada kategori rendah. Selanjutnya, penelitian oleh Adiasih (2015) menunjukan 9,7\% kepercayaan diri siswa berada pada kategori sangat tinggi, 24,2\% berada pada kategori tinggi, $37,1 \%$ berada pada kategori sedang, 22,6\% berada pada kategori rendah, dan $6,5 \%$ berada pada kategori sangat rendah.

Berdasarkan latar belakang diatas maka peneliti tertarik untuk melakukan penelitian yang berjudul hubungan citra tubuh terhadap kepercayaan diri pada remaja putri di MA Sabilul Hasanah Banyuasin Tahun 2019.

\section{METODE PENELITIAN}

Desain penelitian menggunakan kuantitatif dengan metode survey analitik melalui pendekatan cross sectional. Populasi dalam penelitian ini adalah semua remaja putri kelas 1 dan 2 MA Sabilul Hasanah Banyuasin tahun 2019 sebanyak 229. Sampel penelitian berjumlah 68 orang, teknik pengambilan sampel menggunakan accidental sampling. Instrumen penelitian menggunakan kuesioner. Analisis bivariat menggunakan uji $\mathrm{T}$ berpasangan dengan tingkat kemaknaan $(\alpha=0.05)$.

\section{HASIL DAN PEMBAHASAN}

\section{A. Analisis Univariat}

Analisis ini dilakukan untuk memperoleh gambaran tentang distribusi frekuensi responden menurut semua variabel dependen (kepercayaan diri) maupun variabel independent (citra tubuh)

Tabel 3.1

Distribusi Frekuensi Responden Berdasarkan Kepercayaan Diri pada Remaja Putri di MA Sabilul Hasanah Banyuasin Tahun 2019

\begin{tabular}{cccc}
\hline No & $\begin{array}{c}\text { Kepercayaan } \\
\text { Diri }\end{array}$ & Jumlah & $\begin{array}{c}\text { Persentase } \\
(\%)\end{array}$ \\
\hline 1 & Tinggi & 49 & 72,1 \\
2 & Rendah & 19 & 27,9 \\
\hline & Total & $\mathbf{6 8}$ & $\mathbf{1 0 0 , 0}$ \\
\hline
\end{tabular}

Berdasarkan tabel 3.1 didapatkan hasil distribusi frekuensi didapatkan dari 68 responden yang kepercayaan diri tinggi berjumlah 49 responden $(72,1 \%)$ lebih banyak dibandingkan dengan responden yang memiliki kepercayaan diri rendah berjumlah 19 responden $(27,9 \%)$.

Menurut Iswidharmanja, dkk (2013), mendefinisikan percaya diri adalah penilaian yang relatif tetap tentang diri sendiri, mengenai kemampuan bakat, kepemimpinan, inisiatif, dan sifat-sifat lain, serta kondisi-kondisi yang mewarnai perasaan manusia. Adanya percaya diri individu mampu mengenal dan memahami diri sendiri, sementara kurang percaya diri dapat menghambat potensi diri.

Penelitian ini sejalan dengan penelitian yang dilakukan oleh Ifdil, Amandha dan Asmidir (2017) dengan hasil kondisi kepercayaan diri remaja putri pada umumnya berada pada kategori sedang dengan frekuensi sebanyak 28 orang (36\%), kategori rendah sebanyak 21 orang (27\%), kategori tinggi sebanyak 20 orang (26\%), kategori sangat tinggi sebanyak 6 orang $(8 \%)$, dan kategori sangat rendah sebanyak 2 orang (3\%). Temuan ini mengungkapkan kondisi kepercayaan diri remaja putri pada umumnya berada pada kategori sedang. 
Penelitian yang dilakukan oleh Wiranatha dan Supriyadi (2015) persentase yang paling banyak ditemukan pada kategori negatif sebesar 44,3\%. Hal ini menunjukkan bahwa sebanyak 218 responden menilai dan memandang tubuhnya sendiri tidak sesuai dengan harapannya. Sedangkan persentase citra tubuh positif sebesar $42,5 \%$ dengan jumlah responden sebanyak 209 orang. Kategorisasi skor skala kepercayaan diri dibagi ke dalam 4 kategori, yaitu kategori sangat tinggi, tinggi, rendah, dan sangat rendah. Nilai mean dan standar deviasi yang dipakai adalah nilai mean empiris sebesar 67,15 dan nilai standar deviasi sebesar 8,21.

Berdasarkan hasil penelitian, teori dan penelitian terkait peneliti berpendapat bahwa salah satu yang memengaruhi kepercayaan diri adalah penampilan fisik atau bentuk tubuh yang dimilikinya. Penampilan fisik yang sangat berpengaruh pada kepercayaan diri didasarkan bagaimana seseorang melihat kondisi fisik berupa bentuk tubuh ataupun berat tubuh yang ia miliki serta bagaimana penilaian seseorang terhadap fisik yang ia miliki dan bagaimana bentuk yang ia inginkan.

Tabel 3.2

Distribusi Frekuensi Responden Berdasarkan Citra Tubuh pada Remaja Putri di MA Sabilul Hasanah Banyuasin Tahun 2019

\begin{tabular}{cccc}
\hline No & $\begin{array}{c}\text { Citra } \\
\text { Tubuh }\end{array}$ & Jumlah & $\begin{array}{c}\text { Persentase } \\
(\%)\end{array}$ \\
\hline 1 & Tinggi & 44 & 64,7 \\
2 & Rendah & 24 & 35,5 \\
\hline & Total & $\mathbf{6 8}$ & $\mathbf{1 0 0 , 0}$ \\
\hline
\end{tabular}

Berdasarkan tabel 3.2 didapatkan hasil distribusi frekuensi didapatkan bahwa dari 68 responden yang memiliki citra tubuh tinggi berjumlah 44 responden $(64,7 \%)$ lebih banyak dibandingkan dengan responden yang memiliki citra tubuh rendah berjumlah 24 responden $(35,5 \%)$.

Menurut Melliana (2006) body image merupakan suatu pengalaman psikologis yang difokuskan pada sikap dan perasaan individu terhadap keadaan tubuhnya, dan body image tidak selalu sama dengan keadaan tubuh yang sebenarnya atau yang nyata. Sedangkan menurut (Nihayati, dkk, 2015) Citra tubuh adalah kumpulan sikap individu baik yang disadari maupun tidak berharap tubuhnya, termasuk persepsi masa lalu atau sekarang mengenai ukuran, fungsi, keterbatasan, makna, dan objek yang kontak secara terus - menerus (anting, make up, pakaian, kursi roda, dan sebagainya) baik masa lalu maupun sekarang.

Penelitian ini sejalan dengan penelitian yang dilakukan oleh Ifdil, Amandha dan Asmidir (2017) dengan hasil kondisi body image remaja putri pada umumnya berada pada kategori netral dengan frekuensi 39 orang (51\%), kategori positif sebesar 13 orang (17\%), kategori negatif sebesar 12 orang (16\%), kategori sangat positif sebesar 7 orang (9\%), dan kategori sangat negatif sebesar 6 orang (8\%). Temuan ini mengungkapkan secara umum kondisi body image remaja putri berada pada kategori netral.

Penelitian yang dilakukan oleh Amma, Esti dan Sirli (2017) hasil penelitian bahwa sebagian besar $31(86,1 \%)$ remaja memiliki citra diri positif di SMK N 11 Malang kelas XI. Responden yang memiliki citra diri positif diketahui dari $84 \%$ remaja berbadan sehat dengan tidak ada kondisi fisik yang kekurangan, sebanyak $81 \%$ remaja merasa selalu percaya diri dalam melaksanakan tugas yang di berikan oleh guru dan sebanyak $80 \%$ remaja merasa bisa membaur di lingkungan pemuda-pemudi di sekitar rumah serta senang mempunyai banyak teman di mana pun berada.

Berdasarkan hasil penelitian, teori dan penelitian terkait peneliti berpendapat bahwa tingkat body image remaja putri pada umumnya berada pada kategori tinggi. Body image yang negatif ini memacu wanita untuk memperbaiki penampilan mereka. Kebanyakan remaja putri mengungkapkan ketidaknyamanan akan bentuk tubuhnya dan ingin menurunkan berat badannya.

\section{Analisis Bivariat}


Tabel 3.3

Hubungan antara Citra Tubuh dengan

Kepercayaan Diri pada Remaja Putri di MA Sabilul Hasanah Banyuasin Tahun 2019

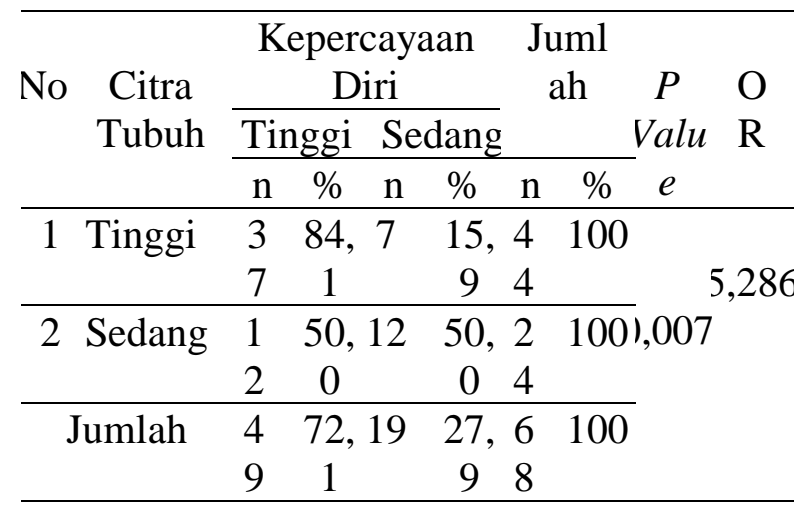

Berdasarkan tabel 3.3 didapatkan

hasil persentase responden yang memiliki citra tubuh tinggi dan kepercayaan diri tinggi sebanyak 37 responden $(84,1 \%)$ lebih besar dari responden yang memiliki citra tubuh rendah dan kepercayaan diri tinggi sebanyak 12 responden $(50,0 \%)$. Hasil uji statistik $p$ value $=0,007$, ini berarti ada hubungan antara citra tubuh dengan kepercayaan diri pada remaja putri di MA Sabilul Hasanah Banyuasin tahun 2019. Dari hasil analisis diperoleh pula nilai OR $=5,286$, artinya siswa yang memiliki citra tubuh tinggi mempunyai peluang 5,286 kali untuk memiliki kepercayaan diri tinggi dibandingkan siswa yang memiliki citra tubuh rendah.

Menurut Iswidharmanja, dkk (2013), mendefinisikan percaya diri adalah penilaian yang relatif tetap tentang diri sendiri, mengenai kemampuan bakat, kepemimpinan, inisiatif, dan sifat-sifat lain, serta kondisi-kondisi yang mewarnai perasaan manusia. Adanya percaya diri individu mampu mengenal dan memahami diri sendiri, sementara kurang percaya diri dapat menghambat potensi diri.

Menurut (Nihayati, dkk, 2015) citra tubuh adalah kumpulan sikap individu baik yang disadari maupun tidak berharap tubuhnya, termasuk persepsi masa lalu atau sekarang mengenai ukuran, fungsi, keterbatasan, makna, dan objek yang kontak secara terus - menerus (anting, make up, pakaian, kursi roda, dan sebagainya) baik masa lalu maupun sekarang.

Penelitian ini sejalan dengan penelitian yang dilakukan oleh Ifdil, Amandha dan Asmidir (2017) Dari hasil temuan diperoleh korelasi antara body image dengan kepercayaan diri menggunakan bantuan SPSS. Nilai koefisien korelasi sebesar 0.788 dengan taraf signifikansi dua jalur sebesar 0,000 pada tingkat taraf kepercayaan 0,01. Dari hasil perhitungan diperoleh nilai signifikansi dua jalur sebesar $0,000<0,01$. Maka dapat disimpulkan $\mathrm{H} 1$ diterima. Artinya, terdapat hubungan yang signifikan antara body image dengan kepercayaan diri remaja putri.

Penelitian yang dilakukan oleh Amma, Esti dan Sirli (2017) hasil uji spearman rank didapatkan $p$ value = $(0,000)<(0,050)$ sehingga H1 diterima, artinya ada hubungan citra diri terhadap tingkat kepercayaan diri remaja siswasiswi SMK N 11 Malang kelas XI. Berdasarkan tabulasi silang didapatkan dari $31(86,1 \%)$ responden yang memiliki citra diri positif didapatkan keseluruhan responden memiliki kepercayaan diri positif juga pada $31(86,1 \%)$ responden, hal ini didukung hasil $r$ value $=0,843$ membuktikan terdapat hubungan positif searah yang kuat antara citra diri dengan tingkat kepercayaan diri remaja, hal ini dapat dipahami bahwa semakin positif citra diri remaja membuat kepercayaan diri remaja meningkat positif.

Berdasarkan hasil penelitian, teori dan penelitian terkait peneliti berpendapat bahwa ada hubungan antara citra diri dengan kepercayaan diri dikarenakan tingkat body image remaja putri pada umumnya berada pada kategori tinggi. Body image yang negatif memacu wanita untuk memperbaiki penampilan mereka. Kebanyakan remaja putri mengungkapkan ketidaknyamanan akan bentuk tubuhnya dan ingin menurunkan berat badannya. Agar remaja memiliki citra diri positif perlu di dukung oleh peran orang tua untuk memuji dan menyayangi anak sehingga anak merasa tidak ada kekurangan dalam dirinya.

SIMPULAN DAN SARAN 


\section{Kesimpulan}

Berdasarkan hasil penelitian tentang hubungan citra tubuh terhadap kepercayaan diri pada remaja putri di MA. Sabilul Hasanah Banyuasin Tahun 2019

Distribusi frekuensi berdasarkan hasil univariat dari 68 responden yang memiliki kepercayaan diri tinggi sebanyak 49 responden $(72,1 \%)$.

1) Distribusi frekuensi berdasarkan hasil univariat dari 68 responden yang memiliki citra tubuh tinggi sebanyak 44 responden $(64,7 \%)$.

2) Ada hubungan antara citra tubuh dengan kepercayaan diri pada Remaja Putri di MA Sabilul Hasanah Banyuasin Tahun 2019

\section{Saran}

.Untuk peneliti selanjutnya ini diharapkan dapat di jadikan dasar pengembangan bagi peneliti selanjutnya untuk membahas tentang kepercayaan diri dengan metode kuantitatif dan kualitatif. Sehingga dapat membantu remaja putri untuk meningkatkan kesadaran dalam meningkatkan kepercayaan diri dan citra tubuh.

\section{DAFTAR PUSTAKA}

Cash, T.F dan Pruzinky, T. (2002) Body Image: A handbook pf theory, Research dan Alinical Practic.

Denich, A. U., \& Ifdil, I. (2015). Konsep Body Image Remaja Putri. Jurnal Konseling dan Pendidikan

Dewi, D.M, dkk (2013). Kepercayaan Diri Dintinjau Dari Pola Asuh Orang Tua Pada Siswa Kelas VII. Indonesian Journal Of Guidance and Counseling Theory and Aplication.

Herlina dan Irianti. (2012). Psikologi Untuk Mahasiswa Kebidanan. Jakarta:Buku Kedokteran EGC

Hidayat, A.A.(2014). Metodelogi Penelitian Keperawatan dan teknis analisis data.Jakarta: Salemba Medika

Enterprise dan Iswidharmanja. (2013). Satu Hari Menjadi Lebih Percaya Diri. Jakarta: Gramedia.

IfdiL dkk. (2017) Hubungan Body Image dengan Kepercayaan Diri Remaja Putri. Jurnal Kajian Bimbingan dan Konseling.

M.Asrori dan M.Ali. (2006). Psikologi Remaja. Bandung: PT Bumi Aksara

Melliana Annastasia. (2006). Menjelajah Tubuh Perempuan dan Mitos Kecantikan. Yogyakarta: Lkis.

Notoatmodjo Soekidjo. (2012). Metodelogi penelitian Kesehatan Edisi

Revisi.Jakarta : Rineka Cipta

Nursalam. (2016). Metodelogi Penelitian

Ilmu Keperawatan Pendekatan Praktis

Edisi 4jakarta : Salemba Medika

Nihayati, dskk (2015). Buku Ajar Keperawatan Kesehatan Jiwa. Jakarta Selatan: Salemba Medika

Risnawita S dan Gufron. (2012). Teori-teori Psikologi. Yogyakarta: Ar Ruzz Media.

Sugiyono (2012.)Metode Penelitian kuantitatif, kualitatif dan $R \& D$. Bandung : Alfabeta

Supardi, S., Rustika. (2013). Buku Ajar: Metodelogi Riset Keperawatan. Jakarta: Trans Info Media

Sujarweni, Wiranata. (2014). Metodelogi Penelitian: Lengkap, praktis, dan mudah dipahami. Yogyakarta: PT Pustaka Baru

Wiranatha dan Supriyadi. (2015) Hubungan Atara Citra Tubuh Dengan Kepercayaan Diri Pada Remaja Pelajar Puteri Di Kota Denpasar. Jurnal Psikologi Udayana. 